\title{
ANALISIS PENERAPAN PELAPORAN KEUANGAN ENTITAS NIRLABA BERDASARKAN PSAK NO. 45 PADA MASJID DI KOTA BANDA
}

\author{
Siti Rahma Nazila*1, Heru Fahlevi ${ }^{* 2}$ \\ ${ }^{1,2}$ Program Studi Akuntansi Fakultas Ekonomi dan Bisnis Universitas Syiah Kuala \\ e-mail: srahmanazila@gmail.com ${ }^{* 1}$, hfahlevi@unsyiah.ac.id ${ }^{{ }^{* 2}}$
}

\begin{abstract}
The purpose of this research is to determine the financial statements of mosques in the city of Banda Aceh in compatible with PSAK No. 45 and the quality of the financial report system of mosques in Banda Aceh. The type of research used in this study is descriptive quantitative method with Probability sampling which is using cluster random sampling. The data used in this study are primary data, namely a questionnaire distributed to 50 respondents from 25 mosques in Banda Aceh City. The questionnaire was distributed to the Head of BKM and Treasurer. The research data was obtained directly from the respondents by filling out the questionnaires that were distributed. The results of this study show that mosques in Banda Aceh City in general have not applied PSAK No. 45 concerning Nonprofit Financial Reporting because mosques do not have financial position reports, activity reports, cash flows, notes to financial statements. Mosques only make simple financial reports covering the sources of income, expenses, and cash balances at the end of the period and the obstacles that cause the mosque to not implement PSAK No. 45 namely the constraints of understanding in the preparation of mosque financial reports according to PSAK No. 45 and lack of human resources with accounting background.
\end{abstract}

Keywords: Organisasi Nirlaba, Laporan Keuangan, PSAK No. 45.

\section{Pendahuluan}

Masjid merupakan salah satu organisasi sektor publik yang tergolong dalam organisasi nirlaba yang dalam menjalankan aktivitasnya mengelola sumber daya yang dimilikinya dan harus mempertanggungjawabkannya termasuk publikasi pertanggungjawaban laporan keuangannya. Standar akuntansi keuangan sebagai pedoman penyusunan dan penyajian laporan keuangan berperan sangat penting agar dalam pembuatannya laporan keuangan lebih berguna, dapat dipahami, relavan, dan mudah untuk diperbandingkan (Nurlaela dan Mutmainah, 2014). Standar akuntansi diatur oleh lembaga akuntansi yaitu Ikatan Akuntan Indonesia (IAI) yang akan mangacu pada teori-teori yang berlaku dan memberikan tafsiran dan penalaran yang mendalam dalam pembuatan laporan keuangan untuk memperoleh informasi yang akurat termasuk juga untuk organisasi entitas nirlaba.

Organisasi nirlaba atau organisasi nonprofit berbeda dengan organisasi bisnis dimana tujuan dari organisasi bisnis adalah mencapai laba sebesar-besar nya sedangkan untuk nirlaba adalah suatu organisasi yang bertujuan tidak komersial, tanpa ada perhatian terhadap hal-hal yang mencari laba. Standar akuntansi untuk penyusunan pelaporan keuangan pada entitas nirlaba telah diatur dan ditetapkan oleh IAI yaitu Pernyataan Standar Akuntansi Keuangan (PSAK) Nomor 45 tentang Pelaporan Keuangan Entitas Nirlaba. Laporan keuangan entitas nirlaba meliputi laporan posisi keuangan pada akhir periode, aktivitas dan arus kas untuk suatu periode pelaporan, dan CaLK.

PSAK 45 yang membahas laporan keuangan entitas nirlaba terdiri dari organisasi agamaan, rumah sakit, sekolah negeri dan organisasi sukarelawan. Masjid yang termasuk dalam organisasi keagamaan memiliki kewajiban untuk mempertanggungjawabkan dana yang diterima dari publik atau donatur dengan cara menyajikan laporan keuangan masjid yang tersusun seperti PSAK Nomor 45. Laporan ini akan digunakan oleh pihak internal dan eksternal, dimana pihak internal bertujuan untuk mengetahui keuangan yang ada dalam masjid tersebut, sedangkan pihak eksternal bertujuan untuk mengetahui apakah dana yang ada telah diperguna dengan baik dan terlampir di laporan keuangan. 
Masjid yang termasuk dalam lembaga non-profit atau nirlaba non pemerintah yang memiliki aktivitas dibidang keagamaan juga memiliki beberapa peran lainnya seperti kegiatan sosial dan pendidikan. Dalam hal ini dengan banyaknya kegiatan yang dilakukan oleh masjid yang pasti mendapatkan dana atau sumbanagan dari berbagai pihak untuk kegiatankegiatan yang akan dilaksanakan seharusnya membuat laporan keuangan yang sesuai dengan format PSAK No. 45, namun dalam hal ini dalam hal ini masih banyak organisasi peribadatan yang berada di Indonesia masih belum secara langsung menerapkannya pada lembaga peribadatan hal ini dibuktikan oleh beberapa penelitian sebelumnya salah satunya pada penelitian Andarsari (2016).

Masjid yang mendapatkan sumber dananya dari sumbangan masyarakat dan para penyumbang lainnya yang tidak mengharapkan imbalan. Untuk itu masjid sebagai organisasi nirlaba harus membuat pelaporan keuangannya agar dapat dilihat oleh pemakai laporan keuangan dan sebagai pengambilan keputusan yang akan dapat meningkatkan kinerja pengelola keuangan masjid dan meningkatkan kepercayaan masyarakat sebagai penyumbang dana (Nariasih, 2015).

Menurut Andarsari (2016), pencatatan pelaporan keuangan masjid biasanya hanya dibuat penerima dan pengeluaran kas tanpa memperlihatkan jumlah asset apa saja yang dipunyai oleh masjid, sehingga informasi yang diberikan kepada para pemakai laporan keuangan yaitu donatur masjid tidak sesuai apa yang terlihat karena kelemahan dalam sistem pencatatan laporan keuangannya. Terdapat perbedaan yang mencolok dari masjid yang satu dengan yang lain, yaitu mempunyai dana cukup besar sedangkan yang masjid lainnya hanya memiliki dana yang minim sehingga pengurus masjid harus mencari sumber dana dari berbagai tempat dan hal ini menjadi citra kurang baik untuk penganut agama lain. Maka dari itu menerapkan sistem keuangan yang bagus akan memberi solusi yang tepat atas ketidakpercayaan publik terhadap organisasi masjid dan takmir masjid.

Penelitian ini bertujuan untuk menjawab pertanyaan kualitas sistem pelaporan keuangan di Masjid Kota Banda Aceh dan bagaimana laporan keuangan masjid di Banda Aceh sudah sesuai dengan standar akuntansi entitas nirlaba yang diatur dalam PSAK No. 45

\section{Kajian Pustaka dan Kerangka Pemikiran Pengertian Organisasi Nirlaba}

Organisasi adalah sebuah peran, aliran aktivitas dan proses (hubungan kerja) yang mengajak beberapa orang sebagai pelaksana tugas yang didesain untuk dicapai tujuan bersama (Torang, 2013). Organisasi suatu entitas sosial yang dilakukan oleh dua orang atau lebih dengan batasan yang relatif diketahui, berfungsi secara terus-menerus untuk mencapai tujuan bersama.

\section{Standar Akuntansi Organisasi Nirlaba Berdasarkan PSAK No. 45}

Di Indonesia, Dewan Standar Akuntansi Keuangan (DSAK) mengeluarkan Pernyataan Standar Akutansi Keuangan No. 45 sebagai standard khusus pelaporan keuagan entitas nirlaba. PSAK 45 yang digunakan saatini, adalah PSAK No. 45 Revisi 2011 yang sebelumnya adalah PSAK 45 terbitan tahun 1997 yang disah oleh DSAK. Peraturan ini diterbitkan agar dapat menjadi acuan untuk organisais nirlaba sebagai standard khusus untuk laporan keuangannya.

\section{Karakteristik Organisasi Nirlaba dalam PSAK No. 45}

Berdasarkan PSAK No. 45, karakteristik PSAK No. 45 Entitas Nirlaba adalah: Pertama, Sumber daya organisasi yang berasal dari para penyumbang yang sukarela tidak mengharapkan imbalan kembali. Kedua, mendapatkan barang/jasa tanpa bertujuan menimbun laba, dalam arti laba yang dihasilkan suatu entitas tidak pernah dibagikan pada pemilik tersebut. Ketiga, Tidak ada kepemilik seperti organisasi laba, yang berarti bahwa kepemilikan pada organisasi nirlaba tidak untuk diperjual, dialihkan atau ditebus kembali atau kepunyaan tersebut tidak menggambarkan proporsi pembagian sumberdaya entitas pada suatu likuidasi atau pembubar entitas. (IAI, 2011).

\section{Laporan Keuangan Organisasi Nirlaba}

Menurut Standar Akuntansi Indonesia (2012:5) definisi laporan keuangan ialah laporan yang menyajikan posisi keuangan dan kinerja keuangan dalam sebuah entitas. Dalam PSAK Nomor 45 (Revisi 2011) menyebutkan tujuan dari suatu laporan keuagan untuk memberikan informasi mengenai:

a. Berapa jumlah dan sifat asset, liability, dan asset neto organisasi nirlaba. 
b. Bagaimana pengaruh transaksi dan aktivitas lain yang merubah nilai dan sifat asset tersebut.

c. Jenis dan jumlah arus masuk dan keluar sumberdaya dalam satu period.

d. Bagaimana Cara organisasi nirlaba memperoleh dan membelanjakan kas, mendapatkan dan melunaskan hutang, dan faktor lainnya terkait likuiditasnya.

e. Usaha jasa nirlaba.

\section{Unsur-Unsur Laporan Keuangan PSAK No. 45}

Berdasarkan PSAK No. 452011 Akuntansi dari organisasi nirlaba meliputi bentuk laporan keuangan dan nama-nama rekening. Unsur-unsur laporan keuangan menurut PSAK No.45 meliputi:

1. Laporan Posisi Keuangan

Memberi informasi yang relavan mengenai likuiditas, fleksibility keuangan, dan hubungan antara asset dan liability.

2. Laporan Aktivitas

Organisasi nirlaba secara menyeluruh dan memberikan informasi perubahan jumlah aset neto yang terdiri dari terikat permanen, temporer, dan tidak terikat dalam suatu periode.

3. Laporan Arus Kas

Penyajian laporan arus kas dikelompokkan menjadi 3 tipe yaitu, Aktivitas Operasi, Investasi dan Pendanaan.

4. Catatan atas Laporan Keuangan

CaLK bertujuan memberi seluruh informasi keuangan yang dikira perlu untuk diketahui penggunanya.

\section{Siklus Akuntansi Organisasi Nirlaba}

Halim (2013:464) menjelaskan bahwa siklus akuntansi pada organisasi entitas nirlaba termasuk organisasi masjid, dikelompokkan dalam tiga bagian ialah sebagai berikut:

a. Pencatatan, terdiri dari kegiatan pengidentifikasian dan pengukuran dalam bentuk transaksi dan buku pencatatan, kegiatan pencatatan bukti transaksi ke dalam buku jurnal, dan memindahbukukan (post) dari jurnal berdasarkan kelompok atau jenisnya ke dalam akun buku besar.

b. Pengikhtisaran, terdiri dari menyusunkan neraca saldo berdasarkan akun buku besar, membuat ayat jurnal penyesuaian, menyusun kertas kerja, membuat ayat jurnal penutup, membuat neraca saldo setelah penutupan, membuat ayat jurnal pembalik.

c. Pelaporan atau Financial Statement, yang terdiri dari Laporan Surplus-Defisit, Laporan arus kas, Neraca, dan CaLK.

\section{Definisi Masjid}

Menurut Mukhtar (2008), masjid secara khusus adalah bangunan atau tempat yang didirikan untuk beribadah yang memenuhi syarat dan komponen untuk shalat rawatib (lima waktu) dan sholat jum'at. Menurut Simanjuntak dan Januarsih (2011) masjid merupakan organisasi publik yang memiliki nilai-nilai spiritual Islam dan nilai-nilai spiritual tersebut bertentangan dengan nilai-nilai materialism yang biasa terdapat pada organisasi bisnis atau organisasi sektor publik lainnya.

\section{Pengelolaan Keuangan Masjid}

Dengan konteks peribadatan, manajemen keuangan organisasi peribadatan adalah kegiatan yang dilakukan pengelola tempat peribadatan dalam memanfaatkan dana umat sesuai dengan ketentuan dalam ajaran agama dan kepentingan umat beragama, serta bagaimana mendapatkan dana dari umat dengan aturan yang dibenarkan oleh agama (Halim \& Kusufi, 2014:457).

Dalam pengelolaan keuangan masjid terdapat dua fungsi yaitu:

1. Bagaimana cara pengelola organisasi peribadatan dalam memperoleh dana yang sesuai dengan ajaran agama dan tidak menyusahkan umat.

2. Meliputi pertanggungjawaban pengelolaan dana. Hal ini sesuai dengan yang dijelaskan oleh Ayub dalam Halim dan Kusufi (2014:457) tentang konteks organisasi masjid, bahwa keuangan masjid meliputi bagaimana cara mengumpulkan dana, sumber pendanaan, pertanggungjawaban dan pengelolaan dana masjid.

\section{Metode Penelitian Desain Penelitian}

Tujuan penelitian ini bertujuan untuk mengetahui laporan keuangan masjid di kota Banda Aceh sesuai dengan PSAK No. 45 dan mengapa masjid menyusun/tidak menyusun laporan keuangan berdasarkan PSAK. Jenis penelitian yang dipakai 
dalam peneliti ini adalah dengan menggunakan metode kuantitatif deskriptif (Sugiyono, 2013). Tingkat intervensi peneliti dalam penelitian ini adalah minimal. Situasi penelitian tidak diatur. Horizon waktu yang digunakan adalah dimensi waktu one shot dan cross sectional, yaitu data dikumpulkan sekaligus/satu tahap dalam satu periode yang dilakukan dengan cara mengumpulkan kuesioner dari masing-masing responden di masjid. Kuesioner ini di tuju kepada Kepala BKM Masjid dan Bendahara Masjid pada 25 Masjid yang bekerja pada Masjid di Kota Banda Aceh.

\section{Tempat dan Waktu Penelitian}

Lokasi penelitian merupakan suatu tempat atau wilayah dimana penelitian tersebut akan dilakukan. Adapun penelitian yang dilakukan mengambil lokasi di masjid Kota Banda Aceh. Waktu penelitian dimulai dari akhir Februari 2018 s/d awal Mei 2018 di mulai pada saat pengambilan data pertama mengenai gambaran umum sampai selesai untuk pengambilan data.

\section{Populasi dan Sampel Penelitian}

Populasi dalam penelitian ini adalah seluruh masjid yang ada di kota Banda Aceh yang berjumlah 104 masjid (www.simas.kemenag.go.id). Sampel dalam penelitian ini adalah 25 masjid besar yang dilihat dari luas tanah dan bangunannya pada setiap kecamatan di kota Banda Aceh. Pengambilan sampel dalam penelitian ini dengan teknik Probability sampling dengan menggunakan cluster random sampling.

Tabel 3.1

Jumlah Sampel Penelitian

\begin{tabular}{|c|l|l|}
\hline No & \multicolumn{1}{|c|}{ Kecamatan } & \\
\hline 1 & Banda Raya & Masjid Nurul Huda Masjid \\
\hline 2 & Banda Raya & Masjid Baitul Musyahadah \\
\hline 3 & Banda Raya & Masjid As-Shadaqah \\
\hline 4 & Baiturrahman & Masjid Baiturrahman \\
\hline 5 & Baiturrahman & Masjid Makam Pahlawan \\
\hline 6 & Baiturrahman & Masjid Baiturahim \\
\hline 7 & Kuta Alam & Masjid Al-Makmur Lampriet \\
\hline 8 & Kuta Alam & Masjid Al-Furqan \\
\hline 9 & Kuta Alam & Masjid Babuttaqwa \\
\hline 10 & Kuta Raja & Masjid Bani Salim \\
\hline 11 & Kuta Raja & Masjid Tgk. Chik Dianjong \\
\hline 12 & Syiah Kuala & Masjid Jami' Silang \\
\hline 13 & Syiah Kuala & Masjid Darul Falah \\
\hline 14 & Syiah Kuala & Masjid Syuhada \\
\hline 15 & Syiah Kuala & Masjid Baitussalam \\
\hline 16 & Meuraxa & Masjid Babussalam \\
\hline 17 & Meuraxa & Masjid Baiturrahim, Ulee Lheue \\
\hline 18 & Meuraxa & Masjid Syekh Abdurauf \\
\hline 19 & Ulee Kareng & Masjid Baitusshalihin \\
\hline 20 & Ulee Kareng & Masjid Baitul Mukminin \\
\hline 21 & Ulee Kareng & Masjid Raudhatul Jannah \\
\hline 22 & Leungbata & Masjid Jami' Leung Bata \\
\hline 23 & Leungbata & Masjid Al-A'la \\
\hline 24 & Jaya Baru & Masjid Subulussalam \\
\hline 25 & Jaya Baru & Masjid Baburrahmah \\
\hline
\end{tabular}

Sumber: Sistem Informasi Masjid Kementerian Agama Republik Indonesia (2018) 


\section{Objek dan Subjek Penelitian}

Objek yang digunakan dalam penelitian ini adalah masjid di Kota Banda Aceh. Subjek dari penelitian ini adalah Kepala BKM Masjid dan Bendahara Masjid yang dianggap memiliki pengetahuan atas pengelolaan di bidang keuangan masjid.

\section{Jenis dan Sumber Data}

Penelitian termasuk dalam penelitian kuantitatif dan yang digunakan data primer berupa kuesioner sebagai sumber data dan data sekunder. Kuesioner terdiri atas pernyataan-pernyataan yang dibentuk dari PSAK No. 45. Kuesioner penelitian ini untuk dapat dianalisis tentang penerapan laporan keuangan masjid berdasarkan PSAK No. 45. Sedangkan data sekunder dokumen-dokumen yang berasal dari masjid misalnya laporan keuangan, sejarah masjid dan struktur organisasi.

\section{Teknik Pengumpulan Data}

Pengukuran dimensi dan indikator atau elemen penelitian ini menggunakan skala Guttman dengan rentang nilai dari 1 sampai 2 poin. Menurut Sugiyono (2014:139) Skala Guttman, skala yang diperguna untuk menghasil jawaban tegas dari responden, yaitu hanya terdapat dua pilihan seperti "setuju-tidak setuju".

Peneliti juga membuat kategori untuk menentukan masjid mana yang memiliki sistem akuntansi yang baik sesuai dengan PSAK No. 45. Terdapat 4 kategori untuk menentukannya berdasarkan range score yang didapati dari jumlah pertanyaan kuesioner yaitu 34 pertanyaan kemudian dikalikan dengan skor jawaban "Ya" yaitu "2". Sehingga didapat range score tertinggi yakni 68 yang berarti sistem akuntansi sudah sesuai dengan PSAK No. 45.

Tabel 3.2

Kategori Masjid

\begin{tabular}{|c|l|c|}
\hline No & \multicolumn{1}{|c|}{ Kategori } & Range Score \\
\hline 1 & Sistem Akuntansi Sudah Sesuai dengan PSAK No. 45 & $52-68$ \\
\hline 2 & Sistem Akuntansi Sudah Menerapkan Sebagian PSAK No. 45 & $35-51$ \\
\hline 3 & Sistem Akuntansi Belum/Hanya Menerapkan PSAK No. 45 & $18-34$ \\
\hline 4 & Sistem Akuntansi Masih Sangat Sederhana & $1-17$ \\
\hline
\end{tabular}

Sumber: Data Primer, diolah (2018)

\section{Teknik Analisis Data}

Penelitian ini menggunakan pendekatan kuantitatif dengan penggunaan data primer yaitu kuesioner. Data primer yang diperoleh selanjutnya akan dianalisis. Teknik analisis yang digunakan adalah:

1. Analisis Deskriptif, teknik ini dipakai untuk menganalisis data dengan mendeskripsikan atau mengambarkan data-data yang sudah dikumpulkan seadanya tanpa ada maksud membuat generalisasi dari hasil penelitian.

2. Distribusi Frekuensi, sebuah tabulasi angka masing-masing individu yang diatur dalam beberapa kategori dalam skala pengukuran. Distribusi frekuensi menunjukan berapa banyak subjek/objek yang memiliki nilai yang sama dan terukur dalam variabel.

\section{Hasil Penelitian dan Pembahasan Deskripsi Objek Penelitian}

Data dalam penelitian ini merupakan data primer dengan menggunakan kuesioner sebagai sarana pengambilan datanya. Kuesioner didistribusikan kepada 50 responden pada 25 Masjid di Kota Banda Aceh yang menjadi sampel penelitian. Jumlah kuesioner yang kembali sebanyak 40 kuesioner atau sebesar $80 \%$ kuesioner yang kembali. Responden dalam penelitian ini memiliki karakterisktik yang tidak sama. Dari sebaran angket, dijelaskan berdasarkan usia responden berusia 21-30 tahun sebesar 7,5\%, usia $31-40$ tahun adalah sebesar 32,5\%, dan usia diatas 40 tahun adalah $60 \%$. Untuk karakteristik pendidikan terbanyak adalah Strata I sebesar 42,5\%.

\section{Struktur Organisasi Masjid}

Struktur organisasi adalah suatu bagan yang dibagi tugas melaksanakan berbagai aktivitas atau tugas yang harus dilakukan untuk mencapai tujuan 
yang dirancang oleh organisasi tujuan utama suatu masjid adalah memberikan pelayanan peribadatan bagi jamaah (Khairaturrahmi, 2017).

Struktur kepengurusan masjid terdiri dari:
1. Ketua
2. Sekretaris
3. Bendahara
4. Bidang Idarah
5. Bidang Imarah
6. Bidang Ria'yah

\section{Kesesuaian Pelaporan Akuntansi Masjid Terhadap PSAK No. 45}

Hasil penelitian ini menunjukkan bahwa seluruh masjid yang diteliti sudah membuat laporan keuangan secara rutin dan memcatat setiap transaksi keuangan dilengkapi dengan bukti-bukti. Masjid juga sudah transparan menyampaikan informasi keuangan masjid melalui papan informasi masjid dan print out, namun belum ada masjid yang menyusun laporan keuangan sesuai dengan format pencatatan laporan keuangan PSAK No. 45.

Hasil penelitian ini sesuai dengan hasil penelitian Marsdenia (2015) yaitu kedua masjid yang berlokasi di Jawa Barat diteliti belum mengacu pada PSAK secara seluruhan atau laporan keuangan yang dibuat sudah ada tapi tidak memenuhi PSAK 45. Namun mengenai transparansi bertolak belakang dengan penelitian ini dimana salah satu masjid belum transparan pada jamaah kecuali laporan masukan dan keluar shalat jum'at, lebaran haji dan idul fitri.

Hasil penelitian ini sejalan dengan penelitian Fitria (2017) yaitu sebagian besar masjid di Balikpapan tidak dapat menampilkan laporan keuangan lengkap karena kerahasiaan laporan keuanganya. Penelitian ini di dukung penelitian Tinungki \& Pusung (2014) yaitu laporan keuangan panti belum sesuai dengan susunan format laporan keuangan nirlaba PSAK No. 45. Begitupun dengan hasil penelitian yang didapatkan Leiwakabessy (2015), yaitu pada GMIM Baitel Kolongan yaitu kegiatan akuntansi yang ada pada GMIM Baitel Kolongan sudah berjalan dengan baik, tetapi dalam hal pelaporan keuangan tidak sesuai dengan PSAK No. 45 karena GMIM Baitel Kolongan mempunyai landasan sendiri yaitu mengikuti format laporan keuangan dari Badan Pengawas Majelis Sinode (BPMS).
Dari hasil penelitian juga dapat diketahui masjid sudah membuat laporan neraca, laporan aktivitas, laporan kas dan CaLK. Namun, hasil berbeda dengan data informasi keuangan yang peneliti dapatkan berupa laporan keuangan dalam bentuk print out atau pun papan informasi masjid dimana laporan yang dibuat masjid mempaparkan tentang sumber dan pengguna dana serta saldo setiap bulannya yang bila disesuaikan dengan standard yang berlaku yaitu PSAK 45 menunjukkan laporan yang dibuat masih dalam laporan arus kas saja belum mengacu pada PSAK 45 yang terdiri dari laporan neraca, laporan aktivitas, laporan kas, dan CaLK.

Hasil penelitian ini sejalan dengan penelitian Andikawati \& Winarno (2014) menunjukkan bahwa Masjid Agung Anaz Mahfudz dan Masjid Al-Huda Lumajang belum menerapkan PSAK 109 atau PSAK 45 dalam laporan keuangannya, bentuk laporan keuangan berupa laporan sederhana. Begitu juga dengan penelitian Marsdenia (2015) dimana hasil penelitiannya menunjukkan bahwa penerapan PSAK 45 pada kedua masjid di Jawa Barat sangat terbatas, karena tidak berbasis akrual, hanya berbasis kas yang sangat sederhana dan pelaporan keuangan sederhana.

\section{Kualitas Sistem Akuntansi dan Pelaporan Keuangan Masjid di Kota Banda Aceh}

Hasil penelitian ini menyatakan bahwa kualitas sistem akuntansi dalam pelaporan keuangan masjid di Kota Banda Aceh masih jauh dari yang diharapkan sesuai dengan PSAK No. 45, hal ini terlihat pada laporan keuangan masjid yang disusun secara sederhana yang hanya menginformasikan sumber penerimaan, pengeluaran, dan saldo kas di akhir periode. Ini sangat berbeda dengan penyusunan laporan keuangan yang ditetapkan PSAK.

Memiliki sistem akutansi dan pelaporan keuangan masjid yang memberikan manfaat dan keuntungan seperti masyarakat akan lebih percaya bahwa pengelolaan masjid dikelola dengan baik dan penuh pertanggungjawaban, sehingga para jamaah atau donatur akan lebih antusias dengan keikhlasan dalam bersedekah maupun melakukan ibadah lainnya.

Hasil penelitian ini sejalan dengan penelitian Mamesah (2013) yaitu Gereja Efrata Sentrum belum mempunyai kualitas informasi laporan keuangan yang memenuhi syarat dalam penyampaian penjelasan untuk para pemakai laporan keuangannya seperti 
mudah dipahami, relevan, dapat diandalkan dan dapat diperbandingkan. Begitu juga dalam penelitian Diptyana (2011) menunjukkan bahwa praktek akuntansi di organisasi masjid di Surabaya masih beragam, pemaparan yang dilakukan secara sukarela dan bermacam kebutuhan informasi para pengguna dapat menjadi penyebab adanya ragaman ini.

Kualitas sistem akuntansi dan pelaporan keuangan masjid belum sesuai dengan PSAK No. 45 disebabkan oleh beberapa kendala dalam penyusunan laporan keuangan masjid. Dari hasil penelitian beberapa masjid memiliki kendala dalam menyusun laporan keuangannya seperti:

1) Belum adanya SDM yang mempunyai latar belakang ilmu akuntansi atau tenaga pembukuan sepenuhnya memahami tentang PSAK.

2) Kendala pemahaman dalam menyusunan laporan keuangan masjid menurut PSAK No. 45

3) Pengurus masjid seperti BKM dan Bendahara memiliki keterbatasan waktu untuk penyusunan laporan keuangan masjid seperti PSAK 45 sehingga hanya membuat pelaporan keuangan masjid secara sederhana saja.

Meskipun terdapat kendala diatas, beberapa masjid berpendapat bahwa kualitas sistem akuntansi dan pelaporan keuangan masjid sudah jelas dan sesuai dengan tuntutan masyarakat, namun belum sempurna karena laporan keuangan dibuat cukup sederhana dengan bentuk buku kas yaitu hanya menerangkan penerimaan dan pengeluaran.

Berbeda dengan hasil penelitian Raya (2017) yaitu Gereja Paroki memiliki SDM yang kompeten dalam menyusun dan menyajian laporan yang baik, sehingga paroki tidak ditegur dari keuskupan karena terlambat mengirim laporan atau tidak menyaji laporan keuangan.

Penyebab lain dari belum sempurnanya kualitas sistem akuntansi dan pelaporan keuangan masjid adalah tidak adanya peringatan atau sanksi yang diberikan pemerintah dalam penyusunan laporan keuangan masjid jika laporan tersebut belum seperti PSAK 45. Jika memang ada sanksi atau peringatan itu hanyalah dari para jamaah atau donatur dikarenakan keterlambatan atau ketidaktepatan dalam menyampaikan informasi keuangan masjid. Di samping itu sebenarnya mengelola keuangan serta menyusun laporan keuangan masjid yang baik merupakan sebuah ibadah yang dianjurkan oleh AlQur'an dan Hadist. Laporan keuangan adalah bagian dari sebuah pertanggungjawaban maka setiap pertanggungjawaban adalah bagian dari perintah agama. Jadi, sudah selayaknya setiap masjid membuat laporan keuangan dengan lebih rinci dan sesuai regulasi yang ditetapkan bukan hanya karena adanya penghargaan tapi keikhlasan dalam beribadah.

\section{Kesimpulan, Keterbatasan dan Saran}

Berdasarkan bahasan hasil penelitian dan analisis data yang telah dipaparkan sebelumnya, dapat disimpul bahwa:

1) Masjid di Kota Banda Aceh secara umum belum menerapkan PSAK 45 tentang pelaporan keuangan nirlaba dikarena masjid belum memiliki 4 unsur laporan keuangan psak 45. Masjid hanya membuat laporan sederhana meliputi sumber penerimaan, pengeluaran, dan saldo kas di akhir periode.

2) Masjid di Kota Banda Aceh secara umum belum menerapkan PSAK No. 45 karena kurangnya motivasi dalam penerapannya, penyebabnya adalah tidak adanya sanksi bagi masjid jika tidak menerapkan PSAK No. 45 dan tidak ada penghargaan bagi masjid jika menerapkan PSAK No. 45. Selain itu terdapat beberapa kendala yang menyebabkan masjid di Kota Banda Aceh belum menerapkan PSAK No. 45 yaitu kurangnya sumber daya manusia yang mempunyai latar belakang ilmu akuntansi menyebabkan masjid tidak mampu menyusun laporan keuangan sesuai PSAK No. 45

Penelitian ini memiliki keterbatasan yang dapat jadikan timbangan bagi peneliti selanjutnya agar diperoleh hasil yang baik di waktu mendatang, antaranya adalah:

1) Penelitian ini kurang menggambarkan keadaan laporan keuangan masjid, karena penulis tidak mendapatkan laporan keuangan masjid secara langsung.

2) Beberapa kuesioner diisi oleh responden yang bukan kepala BKM atau Bendahara masjid secara langsung, tetapi diwakilkan oleh orang lain.

3) Data yang dikumpulkan hanya melalui kuesioner. 
Berdasarkan pembahasan penelitian, simpulan dan batasan pada penelitian ini yang telah dipaparkan sebelumnya, adapun saran-saran yang dapat diberikan:

1) Bagi peneliti selanjutnya yang juga ingin meneliti laporan keuangan masjid alangkah baiknya mendapatkan data laporan keuangan masjid agar penelitian valid.

2) Sebaikya posisi bendahara ditempati oleh orang yang memiliki latar belakang akuntansi sehingga lebih mudah memahami dan menyusun laporan keuangan sesuai PSAK No. 45.

3) Pemerintah harusnya melakukan pembinaan yang intensif mengenai pelaporan keuangan masjid menurut PSAK No. 45.

4) Bagi pemerintah, ada baiknya melakukan audit terhadap laporan keuangan masjid.

\section{DAFTAR PUSTAKA}

Accounting Principle Board (APB). 1970. Statement. 4. Basic Concepstand Principles Underlying Financial Statement of Business Enterprise. Amerika Serikat.

Andarsari, P. Rosita. 2012. Laporan Keuangan Organisasi Nirlaba (Lembaga Masjid) STMIK Malang. Jurnal Ekonomi Universitas Kediri.

Andikawati, Desy dan Wahyu Agus Winarno. 2014. Laporan Keuangan Lembaga Masjid (Studi Kasus Pada Lembaga Masjid Agung Anaz Mahfudz Dan Masjid Al- Huda Lumajang). ARTIKEL ILMIA MAHASISWA 2014. Universitas Jember. Jember.

Ayub, Muhammad. 1996. Manajemen Masjid. Jakarta: Penerbit Gema Insani

Basri, Hasan \& A. K. Siti Nabiha, and M. Shabri Abd. Majid. 2016. Accounting and Accountability in Religious Organizations: An Islamic Contemporary Scholars' Perspective. Gadjah Mada International Journal of Bussines ISSN 1141-1128 No.2. Vol. 18. Universitas Syiah Kuala. Banda Aceh.

Diptyana, Pepie. 2011. Studi atas Praktik Akuntansi di Organisasi Masjid di Surabaya. The Indonesian Accounting Review No.1. Vol. 1. Januari 2011, page 73-81. STIE Perbanas. Surabaya.

Fitria, Yunita. 2017. Akuntabilitas pasa Organisasi Religi; Studi Kasus Masjid-Masjid di Balikpapan, Kalimantan Timur. AKUNTABEL
ISSN Print: 0216-7743 ISSN ONLINE: 2528115 No.1. Vol. 14. Universitas Mulawarman. Samarinda.

Gultom, Ignasius Rian dan Agus T. Poputra. 2015. Analisis Penerapan PSAK NO. 45 Tentang Laporan Keuagan Organisasi Nirlaba Dalam Mencapai Transparansi Dan Akuntabilitas Kantor Sinode GMIM. Jurnal EMBA ISSN 2303-1174 No.4.Vol 3. Universitas Sam Ratulangi. Manado.

Halim, Abdul dan M. Syam Kusufi. 2014. Teori, Konsep, Dan Aplikasi Akuntansi Sektor Publik Dari Anggaran Hingga Laporan Keuangan, Dari Pemerintah Hingga Tempat Ibadah, Edisi ke-2. Jakarta: Penerbit Salemba Empat.

Hendrawan, Rony 2011. Analisis Penerapan PSAK No. 45 Tentang Pelaporan Keuangan Organisasi Nirlaba Pada Rumah Sakit Berstatus Badan Layanan Umum (Studi kasus di RSUD Kota Semarang). Universitas Diponegoro.

Hery. 2013. Teori Akuntansi - Suatu Pengantar. Lembaga Penerbit Fakultas Ekonomi Universitas Indonesia. Jakarta.

Ikatan Akuntansi Indonesia (IAI). 2011. Pernyataan Standar Akuntansi Keuangan (PSAK) No. 45 Tentang Standar Akuntansi Untuk Entitas Nirlaba.

Ilyas, M. Muchtar. 2008. Tipologi Masjid, Direktorat Urusan Agama Islam Dan Pembinaan Syariah Direktorat Jenderal Masyarakat Islam Departemen Agama. Jakarta.

Khairaturrahmi. 2017. Akuntabilitas dan Transparansi Pengelolaan Keuangan Masjid di Kota Banda. Skripsi. Banda Aceh: Program Studi S1 Akuntansi. Univesritas Syiah Kuala. Banda Aceh

Kuncoro, Mudrajad. 2009. Metode Riset Untuk Bisnis \& Ekonomi. Penerbit Erlangga. Jakarta.

Korompis, Claudia. 2014. Penerapan PSAK NO. 45 Tentang Pelaporan Keuangan Organisasi Nirlaba Pada Sanggar Seni Budaya Logos Ma'Kantar. Jurnal Riset Akuntansi Going Concern. Hal. 16-30.

Leiwakabessy, L. P., 2015. Analisis Penerapan Akuntansi Organisasi Nirlaba Entitas Gereja Berdasarkan Pernyataan Standar Akuntansi Keuangan No. 45 Studi Kasus Gereja Masehi 
Injili Di Minahasa Baitel Kolongan. Skripsi. Manado: Program Studi D4 Akuntansi Keuangan Politeknik Negeri Manado.

Mamesah, Melisa. 2013. Penerapan PSAK No. 45 Pada GMIM Efrata Sentrum Sonder Kaitannya Dengan Kualitas Informasi Laporan Keuangan. Jurnal EMBA ISSN 2303-1174 No.4. Vol 1. Universitas Sam Ratulangi. Manado.

Mardiasmo, 2009. Akuntansi Sektor Publik. Yogyakarta: Penerbit ANDI.

Marsdenia, 2015. Revitalisasi Fungsi Masjid Sesuai Zaman Rasulullah Melalui Implementasi PSAK 45: Studi Empiris Pada Masjid A dan B. ISSN 2302-9791. Vol.2 No.1. Sultan Agung Islamic University.

Masrizal. 2011. Pemberdayaan Masjid. Melalui https://maszal.blogspot.co.id/

2011/03/pemberdayaanmasjid29.html/m=0 [21/09/17]

Mulyadi. 2013. Sistem Akuntansi. Jakarta: Salemba Empat.

Nariasih, Dewi. 2015. Laporan Keuangan Masjid Kombinasi PSAK Nomor 45 Tentang Pelaporan Keuangan Entitas Nirlaba Dan PSAK Nomor 109 Tentang Akuntansi Zakat Dan Infak/Sedekah (Studi Kasus Pada Masjid $X Y Z$ ). Skripsi. Jember: Program Sarjana Universitas Jember.

Nurlaela, Siti dan Mutmainah. 2014. Implementasi PSAK No. 45 Dalam Pelaporan Keuangan Entitas Nirlaba Berstatus Badan Layanan Umum. Jurnal Paradigma ISSN 1693-0827 Vol. 12, No. 01. Universitas Islam Batik. Surakarta.

Pontoh, Chenly Ribka S. 2013. Penerapan Laporan Keuangan Organisasi Nirlaba Berdasarkan PSAK No. 45 Pada Gereja BZL. Jurnal EMBA ISSN 2303-1174 No.3. Vol 1. Universitas Sam Ratulangi. Manado.

Raya, Maya Kurniati Gedi. 2017. Evaluasi Implementasi Pelaporan Keuangansebagai Bentuk Akuntabilitas Organisasi Keagamaan (Studi kasus: Gereja Katolik Paroki St. Paulus Miki Salatiga). Journal of Accounting \& Management Innovation, No.1. Vol 1. January 2017, pp. 01-21. Universitas Kristen Satya Wacana. Salatiga.
Sekaran, Uma \& Roger Bougie. 2013, Research Method for Business: a skill-boarding approach, Sixth Edition. John Wiley \& Sons Ltd.

Simanjuntak, Dahnil Azhar dan Yeni Januarsi. 2011. Akuntabilitas dan Pengelolaan Keuangan di Masjid. SIMPOSIUM NASIONAL AKUNTANSI XIV ACEH 2011. Universitas Syiah Kuala. Banda Aceh.

Sistem Informasi Masjid Kementerian Agama Republik Indonesia. www.simas.kemenag.go.id (diakses 25 November 2017).

Sugiyono (2013). Metode Penelitian Kuantitatif, Kualitatif dan $R$ \& $D$. Bandung: Penerbit Alfabeta.

Tajuddin, Teh Suhaila dan Noor Raudhiah Abu Bakar. 2015. A Comparative Analysis of Performance Management Systems: Case Studies between Masjid in a Public and Private Higher Learning Institutions. Proceeding of the International Conference on Masjid, Zakat and Waqf (IMAF 2015) (e-ISBN 978-967-13087-07). 1-2 December 2015, Shah Alam, Selangor, MALAYSIA. International Islamic University College of Selangor (KUIS).

Tinungki, Angelia N.M, dan Rudy J. Pusung. 2014. Penerapan Laporan Keuangan Organisasi Nirlaba Berdasarkan PSAK No. 45 Pada Panti Sosial Tresna Werdha Hana. Jurnal EMBA ISSN 2303-1174 No.2. Vol 2. Universitas Sam Ratulangi. Manado.

Torang, Syamsir. 2013. Organisasi dan Manajemen (Perilaku, Struktur, Budaya dan Perubahan Organisasi). Cetakan kesatu. Alfabeta, Bandung. 